\title{
Differential Expression of Placental Growth Factor, Transforming Growth Factor- $\beta$ and Soluble Endoglin in Peripheral Mononuclear Cells in Preeclampsia
}

\author{
Zaima Ali1,2, Saba Khaliq¹, Saima Zaki³, Hafiz Usman Ahmad¹ and Khalid Pervaiz Lone1
}

\begin{abstract}
Objective: To measure the peripheral blood mononuclear cells (PBMCs) mRNA expression of placental growth factor (PIGF), Transforming growth factor beta (TGF- $\beta$ ), and soluble Endoglin (sEng) in the blood of preeclamptic and normotensive pregnant women.

Study Design: Cross-sectional analytical study.

Place and Duration of Study: Department of Physiology and Cell Biology, University of Health Sciences, Lahore, from November 2016 to April 2018.

Methodology: The study included 50 normotensive and 57 preeclamptic patients (18-40 years of age), all in the third trimester of pregnancy. The preeclamptic group was further divided into early-onset preeclampsia (EOP) and late-onset preeclampsia (LOP). Blood samples from patients and healthy controls were collected and mRNA expression was measured (18 patients and 18 controls) by real time PCR. Statistical analyses were done using SPSS (version 22). The values were considered significant at 0.05 level of significance.

Results: The PBMCs mRNA expression of PIGF, TGF- $\beta$ and sEng were significantly different between the preeclampsia and control group $(p<0.001)$. A significant decrease in expression of TGF- $\beta$ was observed in LOP group compared to controls $(p<0.001)$; whereas, the difference in the expression of EOP compared to controls was not significant $(p=0.12)$. Similar to TGF- $\beta$, the expression of PIGF was significantly decreased among EOP and LOP compared to controls. Detailed analysis of sEng showed significantly increased expression in both EOP and LOP as compared to healthy group $(p<0.001)$.
\end{abstract}

Conclusion: There is a significant difference in extra-placental expression of PIGF, and sEng in preeclampsia.

Key Words: Preeclampsia, Placental growth factor (PIGF), Transforming growth factor-beta (TGF- $\beta$ ), Soluble endoglin (sEng), Early onset preeclampsia.

\section{INTRODUCTION}

Preeclampsia (PE) is defined as the onset of systolic blood pressure $>140 \mathrm{mmHg}$ or diastolic blood pressure $\geq 90 \mathrm{mmHg}$ at $>20$ weeks of gestation accompanied by 24-hour proteinuria $\geq 300 \mathrm{mg}$ ( $\geq 1+$ on dipstick), in atleast two random urine samples collected 4-6 hours apart. 1 The incidence of disease is reported to be $2-10 \%, 2$ with a seven times higher risk in women in developing countries, $10-25 \%$ of these cases results in maternal death. Abnormal placental development due to disturbance in angiogenesis and impaired trophoblast invasion leads to perfusion disorder in the uteroplacental compartment with resultant hypoxia and

1 Department of Physiology and Cell Biology, University of Health Sciences, Lahore, Pakistan

2 Department of Physiology, Lahore Medical and Dental College, Lahore, Pakistan

3 Department of Obstetrics and Gynecology, Jinnah Hospital, Lahore, Pakistan

Correspondence: Dr. Zaima Ali, Department of Physiology, Lahore Medical and Dental College, Lahore, Pakistan

E-mail: zaima.ali@hotmail.com

Received: July 04, 2018; Accepted: October 29, 2018 endothelial dysfunction. ${ }^{3}$ Placental growth factor and TGF- $\beta$ are proangiogenic proteins with an important role in the process of angiogenesis and embryogenesis. PIGF binds to vascular endothelial growth factor receptor 1 and displaces VEGF to bind to vascular endothelial growth factor receptor 2 (VEGFR-2), the major receptor of signaling cascades in angiogenesis, expressed in cytotrophoblast.4,5 Increased Soluble Fms like tyrosine kinase -1 (sFlt) in preeclampsia, a spliced variant of VEGFR-1 binds PIGF and decreases its bioavailability. 6 Transforming growth factor- $\beta$ regulates the vascular changes during implantation. Along with endoglin, a transmembrane glycoprotein co-receptor it enhances its angiogenic effect through activin receptor like kinase 1 (ALK1) signaling. ${ }^{7}$ Similar to sFIt, increased circulating levels of a soluble form of endoglin, soluble endoglin (sEng) in preeclampsia has been reported by a number of researchers. ${ }^{8-10}$ The sEng binds with circulating TGF- $\beta$, decreasing its bioavailability and interfering with Nitric oxide (NO) mediated vasodilatation with resultant endothelial dysfunction. ${ }^{11} \mathrm{~A}$ number of researchers have studied the mRNA expression of multiple genes in placental tissue,12-14 but a few have done so in the blood of preeclamptic and normotensive group. ${ }^{15-17}$ We hypothesized that mRNA transcript of 
PIGF, TGF- $\beta$ and sEng, highly expressed in placental tissue, is also changed in peripheral blood in preeclampsia. This non-invasive technique can be used to better understand the role of angiogenesis in preeclampsia.

The aim of the study was to measure and compare the mRNA expression of the above, by using real time PCR in preeclamptic and normotensive pregnancies.

\section{METHODOLOGY}

After acceptance from Ethical Review Board, this crosssectional analytical study was conducted according to the guidelines of the Declaration of Helsinki in the Department of Physiology and Cell Biology, University of Health Sciences, Lahore, from November 2016 to April 2018.

Cases included 57 diagnosed preeclamptic women (18-40 years) in third trimester (28-40 weeks), divided into two groups, early-onset preeclampsia (EOP, 28-32 weeks) and late-onset preeclampsia (LOP, 32.1-40 weeks). Fifty normal pregnancies with same maternal and gestational age were selected as controls. Cases with history of smoking, diabetes, renal disease, arthritis, inflammatory bowel disease, chronic hypertension, cardiovascular illness (e.g. ischemic heart disease), or other chronic inflammatory diseases were excluded. Demographic data was compiled along with complete medical, obstetric, and family history.

Five $\mathrm{ml}$ whole blood was collected in EDTA coated vacutainer. After centrifugation at $4000 \mathrm{rpm}$ for 5 minutes, buffy coat was stored at $-20^{\circ} \mathrm{C}$ within an hour of sample collection. FavorPrep total RNA Isolation Kit (Favorgen, Taiwan) was used to extract total RNA following the manufacturer's instructions. Cell-free RNA was quantified using Nano drop and stored at $-80^{\circ} \mathrm{C}$ in RNase-free water.

cDNA was reverse transcribed by using revert aid First Strand cDNA Synthesis kit (Thermo Scientific) following the manufacturer's instructions. Amplification of the cDNA was done by PCR and product confirmed on $2 \%$ agarose gel, using ethidium bromide staining. Genes expression of 18 cases and 18 controls was measured by using specific-primers for Real Time PCR, CFX 96 by using SYBR Green mix (Fermentas, USA), according to the manufacturer's instructions. One $\mu \mathrm{l}$ of cDNA with $8 \mu \mathrm{l}$ of 2 X SYBR Green Real Time PCR Master Mix and $0.5 \mu \mathrm{l}$ of forward and reverse primers was used along with RNase-free water to perform all reactions in a total $10 \mu \mathrm{l}$ mixture (Fermentas, USA). Real time PCR conditions were set at $94^{\circ} \mathrm{C}$ for 4 minutes, followed by 30 cycles of $94^{\circ} \mathrm{C}$ for $30 \mathrm{~s}$, annealing at $60^{\circ} \mathrm{C}$ for 30 seconds, and extension at $70^{\circ} \mathrm{C}$ for $42 \mathrm{~s}$ in a thermal cycle. Primer sequence and PCR product length detail is given in Table I. Samples were assayed in duplicate along with three housekeeping genes.
The statistical analysis was performed using SPSS version 22.0. Clinical parameters were expressed as Means $\pm S D$ (standard deviation). Three housekeeping genes, i.e. GAPDH, $\beta$-actin, and 18srRNA were studied and their mean used to normalize the expression of target. The PBMCs mRNA expression was compared between two groups by students t-test and one-way ANOVA with post-hoc Tukey's test for comparison among the multiple groups (EOP, LOP, and normotensive groups). Differences in gene expressions were reported as fold change with standard deviation (SD). A $p$-value of $<0.05$ was considered statistically significant.

\section{RESULTS}

Details of clinical characteristics of study population are given in Table II. Blood samples from both groups were collected from maternal and gestational age matched females. Based on the recruitment criteria, cases had higher systolic and diastolic blood pressures as compared to controls $(p<0.001)$. There was also a significant difference in mean BMI in both groups $(p<0.001)$.

Gene expression was reported as fold change between the different groups (Figures 1 and 2). The PBMCs

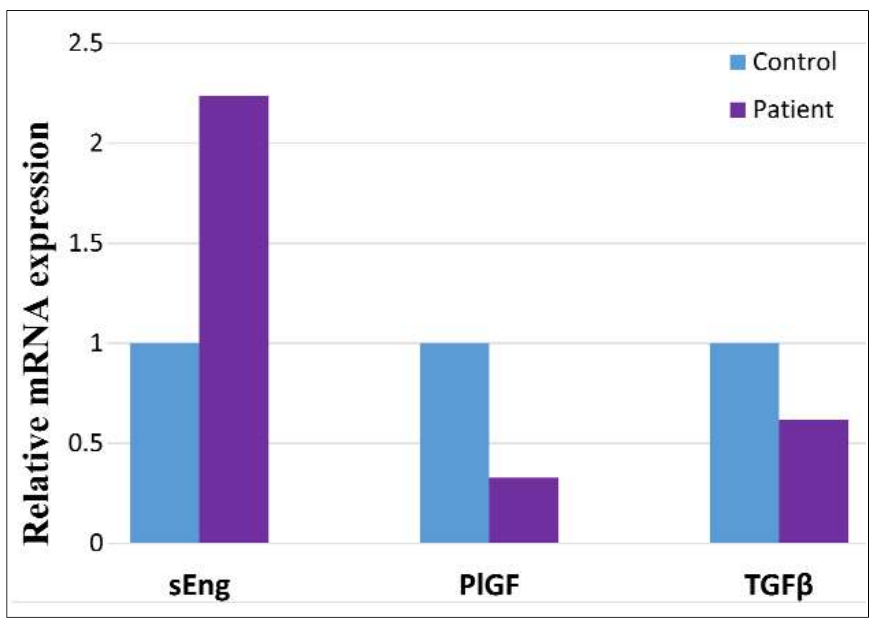

Figure 1: Comparison of PMBCs mRNA expression (fold change) between Normotensive group and Preeclampsia.

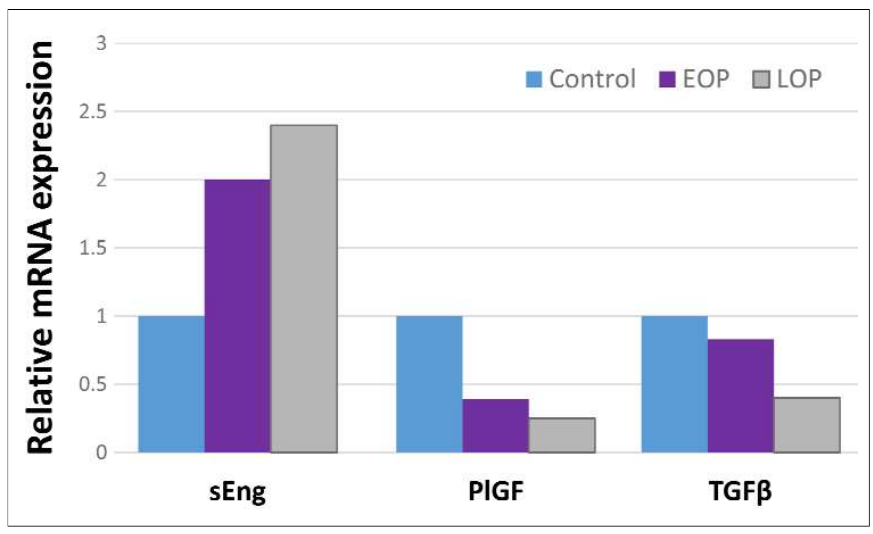

Figure 2: Comparison of PMBCs mRNA expression (fold change) between Normotensive group with EOP and LOP. 
mRNA expression of PIGF and TGF- $\beta$ was significantly different between the preeclampsia and control groups with a decrease in the diseased group $(p<0.001$ for both factors). sEng showed a significant increase (2.24 fold) in PBMCs mRNA expression in the cases $(p<0.001)$ (Table III).

For a detailed knowledge of the differential expression in preeclampsia patients, the group was further divided into EOP and LOP, depending upon the time of onset of the disease. There was a significant difference in the PIGF expression in EOP and LOP with a more profound

Table I: Sequence of primers used for qPCR.

\begin{tabular}{lll}
\hline Gene & Sequence & $\begin{array}{l}\text { PCR } \\
\text { product } \\
\text { length (bp) }\end{array}$ \\
\hline PIGF-FP & 5'- ACG TGG AGC TGA CGT TCT CT - 3' & 241bp \\
PIGF-RP & 5'- CAG CAG GAG TCA CTG AAG AG - 3' & \\
TGF $\beta$-FP & 5'-AGA GCA ACA CGG GTT CAG GTA - 3' & 84bp \\
TGF $\beta$-RP & 5-AGT TCA AGC AGA GTA CAC ACA GCA T-3' & \\
sEng- FP & 5'- AAG TGT GGG CTG AGG TAG- 3' & 109bp \\
sEng- RP & 5' -AGG CGG TGG TCA ATA TCC - 3' & \\
GAPDH-FP & 5' -CGC TCC TGG AAG ATG GTG AT -3' & $214 \mathrm{bp}$ \\
GAPDH-RP & 5' -ACG GAT TTG GTC GTA TTG GG- 3' & \\
$\beta$-actin-FP & 5' -GCA TTT GCG GTG GAC GAT -3' & $75 \mathrm{bp}$ \\
$\beta$-actin-RP & 5' -TCC ACC TTC CAG CAG ATG TG -3' & \\
18s rRNA-FP & 5' -CCT GTA TTG TTA TTT GTC ACT ACC T -3' & $91 \mathrm{bp}$ \\
18s rRNA-RP & 5'-AGA AAC GGC TAC CAC ATC CAA -3' & \\
\hline FP = Forward primer; RP = Reverse primer; bp = base pair. &
\end{tabular}

Table II: Clinical characteristics of PE patients and control group.

\begin{tabular}{l|c|c|c|c}
\hline \multirow{2}{*}{} & \multicolumn{2}{|c|}{ Preeclampsia } & \multirow{2}{*}{$\begin{array}{c}\text { Normotensive } \\
\mathrm{n}=50\end{array}$} & $\mathrm{p}$-value \\
\cline { 2 - 3 } & $\begin{array}{c}\text { Early onset } \\
\mathrm{n}=25\end{array}$ & $\begin{array}{c}\text { Late onset } \\
\mathrm{n}=32\end{array}$ & & \\
\hline $\begin{array}{l}\text { Maternal age } \\
\text { (years) }\end{array}$ & $27.12 \pm 4.8$ & $27.37 \pm 6.1$ & $25.7 \pm 4.6$ & 0.30 \\
\hline BMI $\left(\mathrm{kg} / \mathrm{m}^{2}\right)$ & $29.08 \pm 3.1$ & $28.87 \pm 3.1$ & $25.8 \pm 3.5$ & $<0.001$ \\
\hline Parity & $1.92 \pm 1.9$ & $1.53 \pm 1.7$ & $1.42 \pm 1.3$ & 0.46 \\
\hline $\begin{array}{l}\text { Gestational age at } \\
\text { sampling (weeks) }\end{array}$ & $29.58 \pm 1.7$ & $35.51 \pm 2.1$ & $31.97 \pm 3.1$ & $<0.001$ \\
\hline Systolic BP & $149.6 \pm 15$ & $151.8 \pm 15$ & $105.2 \pm 8.8$ & $<0.001$ \\
\hline Diastolic BP & $97.2 \pm 7.3$ & $97.1 \pm 5.8$ & $67.6 \pm 7.7$ & $<0.001$ \\
\hline
\end{tabular}

Data presented as Mean $\pm S D$, $p$-value $<0.05$ was considered significant, analysed by ANOVA.

Table III: Comparison of mRNA expression between different groups.

\begin{tabular}{|c|c|c|c|c|c|}
\hline Gene & Normotensive & $\begin{array}{l}\text { Preeclampsia } \\
\text { (a) }\end{array}$ & $\begin{array}{l}\text { EOP } \\
\text { (b) }\end{array}$ & $\begin{array}{l}\text { LOP } \\
\text { (c) }\end{array}$ & $\begin{array}{l}p \text {-value } \\
\text { (d) }\end{array}$ \\
\hline PIGF & 1.00 & $0.32 \pm 0.16$ & $0.39 \pm 0.2$ & $0.25 \pm 0.06$ & $\begin{array}{l}\text { a-b }<0.001^{*} \\
\text { c-d }=0.02^{* *} \\
\text { a-c }<0.001^{* *} \\
\text { a-d }<0.001^{* *}\end{array}$ \\
\hline TGF $\beta$ & 1.00 & $0.61 \pm 0.36$ & $0.83 \pm 0.27$ & $0.40 \pm 0.3$ & $\begin{aligned} \text { a-b } & <0.001^{*} \\
\text { c-d } & <0.001^{* *} \\
\text { a-c } & =0.12^{* *} \\
\text { a-d } & <0.001^{* *}\end{aligned}$ \\
\hline sEng & 1.00 & $2.2 \pm 0.45$ & $2.0 \pm 0.32$ & $2.4 \pm 0.44$ & $\begin{array}{l}\text { a-b }<0.001^{*} \\
\text { c-d }<0.011^{* *} \\
a-c<0.001^{* *} \\
\text { a-d }<0.001^{* *}\end{array}$ \\
\hline
\end{tabular}

Data is presented as Mean $\pm S D$, ${ }^{*} p$-value analyzed by students $t$-test for preeclamptic and normotensive groups, ${ }^{* *} p$-value analyzed by ANOVA with post-hoc Tukey's test. $p$-value $<0.05$ was considered significant. decrease in LOP. The expression of TGF- $\beta$ was significantly different between EOP and LOP and showed a significant decrease in LOP compared to controls $(p<0.001)$. However, the difference was not significant in EOP and normotensive group ( $p$-value 0.12 ). Detailed analysis of sEng showed significantly increased expression in both early onset and late onset preeclampsia with a more profound increase of 2.4 fold in LOP as compared to healthy group $(p<0.001)$. The difference was significant in EOP and LOP $(p<0.01$, Table III).

\section{DISCUSSION}

Abnormal placentation with reduced feto-placental perfusion is central to preeclampsia. Defective angiogenesis, being one of the key pathophysiological processes, has been probed in by a number of researchers but the results are controversial. Most of them have reported the serum levels of pro- and antiangiogenic-factors along with mRNA expression in placental tissue. In 2011, Paiva and colleagues worked on both maternal blood and placental tissue in preeclampsia and found correlation of gene expression between the two. 17 mRNA expressions of genes, highly expressed in preeclampsia, have been studied in maternal blood samples by a few others.15,16,18 The present study has analyzed and compared mRNA expression of two proangiogenic factors PIGF and TGF- $\beta$ and an antiangiogenic factor sEng in blood of normotensive and preeclamptic cases. We found a significant decrease in PIGF expression $(p<0.001)$ in the preeclamptic group. The difference was significant within the two subgroups of preeclampsia. The present finding supports the results of a number of studies which have reported a decrease in this proangiogenic factor, providing considerable evidence that disrupted angiogenesis is fundamental to the pathogenesis of preeclampsia.12,15,19 In contrast, Toft et al. worked on placental tissue and found no significant difference in mRNA expression of PIGF between normal and preeclamptic pregnancies. ${ }^{20}$

TGF- $\beta$ has been proposed to have a role in angiogenesis through ALK 1 receptors and maintain vascular health by NO production from (eNOS). A number of studies have reported the expression of TGF- $\beta$ in preeclampsia with mass diversity in results. A significant decrease was found in the mRNA expression of TGF- $\beta$ in preeclampsia $(p<0.001)$. Detailed analysis between the normotensive and two subgroups of preeclampsia revealed significant decrease in TGF- $\beta$ expression in the LOP as compared to the normal pregnancies $(p<0.001)$. However, the difference was not significant between EOP and normotensive controls $(p=0.12)$. The difference within the two subgroups of preeclampsia, i.e. EOP and LOP was significant $(p<0.001)$. Decrease in TGF- $\beta$ expression in preeclampsia, because of its role in 
implantation and angiogenesis, supports the two-stage model of preeclampsia pathology where defective implantation and vasculogenesis lead to a hypoxic state in placenta. ${ }^{3}$ The more profound decrease in the later weeks of gestation in LOP is supported by Singh et al. who reported gradual but significant decrease in expression of TGF- $\beta$ mRNA as the normal gestation proceeds. ${ }^{21}$ Moreover, Martinez-Fierro and colleagues reported significantly lower expression of TGF- $\beta$ in PBMCs as a hallmark of preeclampsia. 22 In contrast, recently in 2017, Wang et al. worked on multiple soluble TGF- $\beta$ receptors in addition to sEng. They reported a significant increase in the levels of these soluble receptors in the serum of EOP with resultant disruption of TGF- $\beta$ signaling and vasculogenesis. 23

Endoglin is a transmembrane co-receptor for TGF- $\beta$ with an important role in endothelial health and relaxation. $s E n g$, a soluble form of the receptor has antiangiogenic properties as it binds the TGF- $\beta$ ligand making it unavailable to initiate intracellular signaling. Resultant decreased production of NO from endothelial NO synthase (eNOS) results in failure of endothelial relaxation and oxidative stress. ${ }^{11} \mathrm{sEng}$ is expressed by syncytiotrophoblast and secreted from placenta in normal pregnancy with gradual increase in the plasma levels as the gestation advances.9,24 In this study, we found a significant 2.24 fold $(p<0.001)$ increase in sEng mRNA in the preeclamptic group as compared to the normal pregnancies. The increase was even more profound in the LOP with a significant difference as compared to normotensive group $(p<0.001)$. This may be attributed to the difference in the gestational age at the time of sampling, as mentioned earlier the levels increase with advancing gestational age. These results support a number of studies which reported increased sEng expression in preeclampsia, both in placental tissue and maternal blood. $15,20,25$

\section{CONCLUSION}

Angiogenesis is disrupted in preeclampsia due to an imbalance between pro- and anti-angiogenic factors with a decrease in PIGF, TGF- $\beta$ and increase in sEng mRNA expression in cellular compartment of blood. Easy accessibility of blood sample makes it a non-invasive tool to diagnose and study the course of preeclampsia. Differences in the early and late onset preeclampsia need further investigation with serial blood sampling during all the three trimesters of gestation.

Disclosure: This research was partially funded from Research Development Fund by University of Health Sciences, Lahore.

\section{REFERENCES}

1. Uzan J, Carbonnel M, Piconne O, Asmar R, Ayoubi JM. Preeclampsia: pathophysiology, diagnosis, and management. Vasc Health Risk Manag 2011; 7:467-74.
2. Osungbade KO, Ige OK. Public health perspectives of preeclampsia in developing countries: implication for health system strengthening. J Pregnancy 2011; 2011:481095.

3. Can M, Sancar E, Harma M, Guven B, Mungan G, Acikgoz S. Inflammatory markers in preeclamptic patients. Clin Chem Lab Med 2011; 49:1469-72.

4. Park JE, Chen HH, Winer J, Houck KA, Ferrara N. Placenta growth factor. Potentiation of vascular endothelial growth factor bioactivity, in vitro and in vivo, and high affinity binding to Flt-1 but not to Flk-1/KDR. J Biol Chem 1994; 269:25646-54.

5. Gille H, Kowalski J, Li B, Le Couter J, Moffat B, Zioncheck TF, et al. Analysis of biological effects and signaling properties of Flt-1 (VEGFR-1) and KDR (VEGFR-2). A reassessment using novel receptor-specific vascular endothelial growth factor mutants. J Biol Chem 2001; 276:3222-30.

6. Takahashi $\mathrm{H}$, Shibuya $\mathrm{M}$. The vascular endothelial growth factor (VEGF)/VEGF receptor system and its role under physiological and pathological conditions. Clin Sci (Lond) 2005; 109:227-41.

7. Lebrin F, Goumans MJ, Jonker L, Carvalho RL, Valdimarsdottir G, Thorikay $\mathrm{M}$, et al. Endoglin promotes endothelial cell proliferation and TGF-beta/ALK1 signal transduction. EMBO J 2004; 23:4018-28.

8. Aggarwal PK, Chandel N, Jain V, Jha V. The relationship between circulating endothelin-1, soluble fms-like tyrosine kinase-1 and soluble endoglin in preeclampsia. J Hum Hypertens 2012; 26:236-41.

9. Levine RJ, Lam C, Qian C, Yu KF, Maynard SE, Sachs BP, et al. Soluble endoglin and other circulating antiangiogenic factors in preeclampsia. N Engl J Med 2006; 355:992-1005.

10. Perucci LO, Gomes KB, Freitas LG, Godoi LC, Alpoim PN, Pinheiro $M B$, et al. Soluble endoglin, transforming growth factor-Beta 1 and soluble tumor necrosis factor alpha receptors in different clinical manifestations of preeclampsia. PloS One 2014; 9:e97632.

11. Toporsian M, Gros R, Kabir MG, Vera S, Govindaraju K, Eidelman $\mathrm{DH}$, et al. A role for endoglin in coupling eNOS activity and regulating vascular tone revealed in hereditary hemorrhagic telangiectasia. Circ Res 2005; 96:684-92.

12. Rabajdova M, Dudic R, Urban P, Dudicova V, Urdzik P, Marekova M. Analysis of transcriptional activities of angiogenic biomarkers during intrauterine complications leading to preterm birth. Eur Rev Med Pharmacol Sci 2017; 21:1433-42.

13. Andraweera PH, Dekker GA, Laurence JA, Roberts CT. Placental expression of VEGF family mRNA in adverse pregnancy outcomes. Placenta 2012; 33:467-72.

14. Kim SC, Park MJ, Joo BS, Joo JK, Suh DS, Lee KS. Decreased expressions of vascular endothelial growth factor and visfatin in the placental bed of pregnancies complicated by preeclampsia. J Obstet Gynaecol Res 2012; 38:665-73.

15. Farina A, Zucchini C, Sekizawa A, Purwosunu Y, de Sanctis P, Santarsiero G, et al. Performance of messenger RNAs circulating in maternal blood in the prediction of preeclampsia at 10-14 weeks. Am J Obstet Gynecol 2010; 203:575.e1-7.

16. Okazaki S, Sekizawa A, Purwosunu Y, Farina A, Wibowo N, Okai T. Placenta-derived, cellular messenger RNA expression in the maternal blood of preeclamptic women. Obstet Gynecol 2007; 110:1130-6. 
17. Paiva P, Whitehead C, Saglam B, Palmer K, Tong S. Measurement of mRNA transcripts of very high placental expression in maternal blood as biomarkers of preeclampsia. J Clin Endocrinol Metab 2011; 96:E1807-15.

18. Ren Y, Wang H, Qin H, Yang J, Wang Y, Jiang S, et al. Vascular endothelial growth factor expression in peripheral blood of patients with pregnancy induced hypertension syndrome and its clinical significance. Pak J Med Sci 2014; 30:634-7.

19. Sekizawa A, Purwosunu Y, Farina A, Shimizu H, Nakamura M, Wibowo $\mathrm{N}$, et al. Prediction of pre-eclampsia by an analysis of placenta-derived cellular mRNA in the blood of pregnant women at 15-20 weeks of gestation. BJOG 2010; 117:557-64.

20. Toft JH, Lian IA, Tarca AL, Erez O, Espinoza J, Eide IP, et al. Whole-genome microarray and targeted analysis of angiogenesis-regulating gene expression (ENG, FLT1, VEGF, PIGF) in placentas from pre-eclamptic and small-for-gestational-age pregnancies. J Matern Fetal Neonatal Med 2008; 21:267-73.

21. Singh M, Orazulike NC, Ashmore J, Konje JC. Changes in maternal serum transforming growth factor beta-1 during pregnancy: a cross-sectional study. Biomed Res Int 2013; 2013:318464.
22. Martinez-Fierro ML, Garza-Veloz I, Carrillo-Sanchez K, Martinez-Gaytan V, Cortes-Flores R, Ochoa-Torres MA, et al. Expression levels of seven candidate genes in human peripheral blood mononuclear cells and their association with preeclampsia. Hypertens Pregnancy 2014; 33:191-203.

23. Wang $Y$, Chen $Q$, Zhao M, Walton K, Harrison C, Nie G. Multiple soluble TGF-beta receptors in addition to soluble endoglin are elevated in preeclamptic serum and they synergistically inhibit TGF-beta signaling. J Clin Endocrinol Metab 2017; 102:3065-74.

24. Romero R, Nien JK, Espinoza J, Todem D, Fu W, Chung H, et al. A longitudinal study of angiogenic (placental growth factor) and anti-angiogenic (soluble endoglin and soluble vascular endothelial growth factor receptor-1) factors in normal pregnancy and patients destined to develop preeclampsia and deliver a small for gestational age neonate. J Matern Fetal Neonatal Med 2008; 21:9-23.

25. Nishizawa $H$, Ota $S$, Suzuki M, Kato T, Sekiya T, Kurahashi $H$, et al. Comparative gene expression profiling of placentas from patients with severe pre-eclampsia and unexplained fetal growth restriction. Reprod Biol Endocrinol 2011; 9:107. 